\title{
Fortifikasi fraksi tidak tersabunkan (ftt) distilat asam lemak minyak sawit pada proses pembuatan roti tawar: implikasi pada sifat fisik dan sensoris
}

Fortification of unsaponifiable matter from palm fatty acid distillate in making bread process: implication to physical and sensory properties

\author{
Kgs Ahmadi), Teti Esitiasih ${ }^{2)}$ \\ ${ }^{1}$ Program Studi Teknologi Industri Pertanian, Universitas Tribhuwana Tunggadewi, \\ Malang, Jawa Timur \\ ${ }^{2}$ Program Studi Ilmu dan Teknologi Pangan, Universitas Brawijaya, Malang, Jawat Timur \\ Email:kgs.ahmadi@yahoo.com; kgsahmadi@unitri.ac.id
}

Informasi Artikel:

Dikirim: 28/04/2020; ditinjau: 30/04/2020; disetujui: 10/08/2020

\begin{abstract}
Palm Fatty Acid Distillate (PFAD) is by product from palm oil industry which contains free fatty acid and bioactive in minor component. Saponification of free fatty acid causes to formation soap and unsaponifiable matter (tocopherol, tocotrienol, phytosterol, and squalene. This research aims to determine the effect fortification unsaponifiable matter on physical and sensory properties of bread. The experiment design used Complete Randomized Design of one factor, namely level of unsaponifiable matter sequentially 0; $0.5 ; 1.0 ; 1.5 ; 2.0$; and $2.5 \%$ in four times replication. Observation parameters of physical properties: developmental volume, texture, and bulk density. While sensory characteristics are color, aroma, taste, and texture. This research showed that fortification of unsaponifiable matter did not affect physical properties (development volume, texture, and bulk density). Sensory test results without unsaponifiable matter fortification are the best treatment for color, aroma, taste, and texture, while among those fortified with unsaponifiable matter the level of $0.5 \%$ is a level that is still acceptable to panelists.
\end{abstract}

Keywords: unsaponifiable matter, bread, palm fatty acid distillate

\begin{abstract}
ABSTRAK
Distilat asam lemak minyak sawit (DALMS) merupakan hasil samping dari pengolahan minyak sawit yang mengandung asam lemak bebas dan senyawa bioaktif dalam jumlah minor. Penyabunan asam lemak bebas menghasilkan sabun hasil reaksi dengan $\mathrm{KOH}$ dan faraksi tidak tersabunkan (FTT) mengandung senyawa bioaktif tokoferol, tokotrienol, fitosterol, dan skualen. Penelitian ini bertujuan untuk mengetahui pengaruh fortifikasi terhadap sifat fisik dan sensoris terhadap roti tawar. Rancangan percobaan yang digunakan adalah Rancangan Acak Lengkap (RAL) 1 faktor, yaitu fortifikasi FTT dengan taraf $0,0,5,1,0,1,5,2,0$, dan 2,5\% dengan 4 ulangan. Parameter pengamatan sifat fisik: volume pengembangan, tekstur, dan densitas kamba. Sementara sifat sensoris adalah warna, aroma, rasa, dan tekstur. Hasil penelitian menunjukkan fortifikasi FTT tidak berpengaruh terhadap sifat fisik (volume pengembangan, tekstur, dan densitas kamba). Hasil uji sensoris tanpa fortifikasi FTT merupakan perlakuan terbaik untuk warna, aroma, rasa, dan tekstur, sementara di antara yang difortifikasi FTT taraf 0,5\% merupakan taraf yang masih dapat diterima panelis.
\end{abstract}

Kata kunci: fraksi tidak tersabunkan, roti tawar, distilat asam lemak minyak sawit 


\section{PENDAHULUAN}

Indonesia saat merupakan negara produsen kelapa sawit dunia. Produksi CPO (Crude Palm Oil) Indonesia pada tahun 2019 mencapai 47,18 juta ton (Gapki, 2020). Crude Palm Oil merupakan bahan baku untuk membuat minyak goreng setelah melalui proses pemurnian. Pada tahapan deodorisasi dari proses pemurnian dihasilkan DALMS (Distilat Asam Lemak Minyak Sawit) yang merupakan hasil samping proses pemurnian (Kapor et al., 2017). Kandungan asam lemak bebas di dalam CPO berkisar antara 3-5\% (Kapor et al., 2017).

Distilat Asam Lemak Minyak Sawit mengandung asam lemak bebas, produkproduk hasil oksidasi dan senyawa-senyawa minor seperti tokoferol, tokotrienol, fitosterol, dan skualen. Menurut Gapoor (2002) DALMS mengandung asam lemak sebagai komponen paling tinggi dan komponen minor vitamin $\mathrm{E}$ (tokoferol dan toktrienol), fitosterol, dan skualen. Hasil penelitian Estiasih et al. (2013) menunjukkan karakteristik DALMS bervariasi menurut pada berbagai perusahaan kandungan asam lemak bebas 85,42 - 92,93\%, vitamin $\mathrm{E}$ (tokoferol dan tokotrienol) 64,70 - $280 \mathrm{ppm}$, fitosterol 407,00 -7476,56 ppm dan skualen 462,87 - 2767,08 ppm, dan sisanya senyawa lain. Posada et al. (2007) menemukan senyawa bioaktif pada DALMS adalah vitamin E $0,5 \%(\alpha$ - tokoferol $23,79 \%, \alpha$ tokotrienol $23,76 \%, \gamma$ - tokotrienol $38,76 \%, \delta$ tocotrienol $13,69 \%$ ), skualen $1,03 \%$, dan fitosterol $0,24 \%$ (campesterol 24,24\%, stigmasterol $18,07 \%, \beta$ - sitosterol 57,68 ). Komposisi DALMS yang demikian maka potensial untuk digunakan sebagai sumber senyawa bioaktif tokoferol, tokotrienol, fitosterol, dan skualen. Akan tetapi untuk dijadikan sebagai sumber sanyawa bioaktif maka harus dilakukan separasi untuk memisahkan senyawa bioaktif dengan lainnya. Separasi bisa dilakukan dengan cara saponifikasi (penyabunan). Saponifikasi menyebabkan asam lemak bebas, produk hasil oksidasi, dan senyawa pengotor lain DALMS membentuk sabun sementara tokoferol, tokotrienol, fitosterol, dan skualen merupakan senyawa yang tidak tersabunkan sehingga dapat dipisahkan. Kandungan senyawa bioaktif pada fraksi tidak tersabunkan (FTT) meliputi vitamin E ( $\alpha$ tokotrieol $6,19-24,72 \%, \delta$ - tokotrienol 2,32 - 31,70, $\gamma$ - tokotrienol $35,15-60,04 \%$, dan $\alpha$ - tokoferol 7,96-47,97\%) dan fitosterol ( $\beta$ sterol 45,63 - 93,75\%, stigmasterol $0,56-$ $25,75 \%$, dan campesterol 2,20 - 28,62\%).

Fraksi Tidak Tersabunkan (FTT) DALMS yang mengandung senyawa bioaktif ini perlu diaplikasi pada produk pangan untuk melihat sampai sejauh mana pengaruh proses terhadap karakteristik fisik produk pangan, konsentarsi senyawa bioaktif setelah proses, dan penerimaan panelis terhadap produk. Proses pengolahan pangan yang melibatkan panas akan berpengaruh terhadap tingkat kerusakan senyawa bioaktif. Senyawa bioaktif (tokoferol, tokotrienol, fitosterol, dan skualen merupakan senyawa yang mudah mengalami kerusakan akibat panas. Roti tawar merupakan produk yang diolah dengan menggunakan panas. Umumnya suhu yang digunakan untuk pembuatan roti antara $200-$ $220^{\circ} \mathrm{C}$ selama 17 menit (Versilovskis dan Barkevics, 2012). Fortifikasi FTT pada roti tawar adalah untuk mengkaji implikasinya terhadap sifat fisik dan sensoris. Penelitian ini bertujuan untuk mengetahui pengaruh fortifikasi terhadap sifat fisik dan sensoris terhadap roti tawar.

\section{METODE}

\section{Bahan dan peralatan}

Bahan yang digunakan dalam penelitian adalah bahan baku utama DALMS yang berasal PT. Salim Ivomas Pratama. Bahan yang digunakan dalam pembuatan roti antara lain tepung terigu, gula, ragi (yeast), garam, bread improver, susu bubuk, margarin, air dingin, dan Fraksi Tidak tersabunkan (FTT) DALMS. Bahan kimia yang digunakan untuk ekkstraksi dan analisis adalah etanol teknis, heksana teknis, $\mathrm{KOH}$ teknis, aquades, etanol p.a (Merck), metanol HPLC Grade (Merck), aquabides, asam askorbat teknis, indikator PP, glukosa 
anhidrat, $\mathrm{H}_{2} \mathrm{SO}_{4}$, alkohol, petroleum eter, asam borat, tablet kjedahl, indikator metil red, $\mathrm{K}_{2} \mathrm{SO}_{4}$, reagen nelson, arsenomolibdat, gas nitrogen. MSTFA (N-Methyl-Ntrimethylsilyl trifluoroacetamide), standar skualen (Santa Cruz Biotechnology), $\alpha$ tokoferol (Nakalai), $\alpha, \delta, \gamma$-tokotrienol (Santa Cruz Biotechnology), fitosterol (stigmasterol, campesterol, dan $\beta$-sitosterol) Sigma Aldrich.

Peralatan yang digunakan adalah labu pemisah, HPLC (Shimadzu), timbangan analitik,, rotary vacuum evaporator "IKA RV 10", shaker water bath "Memmert", freezer, pipet ukur, gelas ukur), spatula, pipet tetes, aluminium foil, dan botol sampel.

\section{Metode}

Metode penelitian yang digunakan dalam penelitian ini adalah Rancangan Acak Lengkap (RAL) dengan satu faktor yang terdiri dari enam taraf. Setiap perlakuan diulang sebanyak empat kali sehingga diperoleh dua puluh empat satuan percobaan.

Faktor: konsentrasi Fraksi Tidak Tersabunkan (FTT) (b/b)

$$
\begin{aligned}
& \mathrm{F} 1=0 \% \\
& \mathrm{~F} 2=0,5 \% \\
& \mathrm{~F} 3=1 \% \\
& \mathrm{~F} 4=1,5 \% \\
& \mathrm{~F} 5=2 \% \\
& \text { F6 }=2,5 \%
\end{aligned}
$$

Uji lanjut menggunakan Duncan's Multiple Range Test

\section{Pelaksanaan penelitian}

Penelitian meliputi proses saponifikasi DALMS, proses pembuatan roti sesuai perlakuan, dan dilanjutkan dengan pengamatan parameter fisik dan organoleptik (sensoris) dengan uji kesukaan (hedonik)

\section{Proses saponifikasi DALMS (Modifikasi} Ahmadi, 1997)

a. Penimbangan DALMS sebanyak 50 gram kemudian dimasukkan ke dalam erlenmeyer $1000 \mathrm{ml}$ yang telah ditutup aluminium foil.

b. Penambahan etanol sebanyak $441,5 \mathrm{ml}$, asam askorbat sebanyak 2,5 gram dan $\mathrm{KOH} \quad 50 \%$ sebanyak $60 \% \quad(\% \quad \mathrm{v} / \mathrm{b}$ DALMS). c. Pemanasan dalam shaker waterbath suhu $70^{\circ} \mathrm{C}$ selama 40 menit.

d. Pendinginan dalam suhu ruang.

e. Pemindahan larutan ke dalam labu pemisah dan ditambahkan heksana sebanyak $375 \mathrm{ml}$ dan akuades sebanyak $500 \mathrm{ml}$.

f. Pengocokan lambat dan pendiaman sampai terbentuk dua lapisan.

g. Pemisahan dalam corong pemisah. Fraksi tersabunkan dalam air (bagian bawah corong) dibuang sedangkan fraksi tidak tersabunkan dalam heksana (bagian atas corong) disimpan.

h. Pemisahan fraksi tidak tersabunkan dalam heksana dengan rotary vacuum evaporator dengan suhu $45^{\circ} \mathrm{C}$ tekanan 200 mbar sehingga diperoleh fraksi tidak tersabunkan (FTT) bebas pelarut.

i. Selanjutnya disemprot Nitrogen sampai bebas pelarut.

\section{Proses pembuatan roti}

a. Penimbangan bahan-bahan sesuai formulasi yang telah ditentukan.

b. Pencampuran bahan awal yaitu tepung terigu, gula pasir, susu bubuk, bread improver, air dingin dan FTT.

c. Pengadukan atau pengulenan secara homogen selama \pm 15 menit.

d. Pencampuran kedua yaitu mentega, garam, dan ragi (yeast).

e. Pengadukan atau pengulenan secara homogen selama \pm 15 menit.

f. Setelah kalis dilakukan pemotongan adonan menjadi 2 bagian sama besar.

g. Dilakukan penggilingan adonan dengan rolling pin dan dibentuk menggulung.

h. Dilakukan fermentasi pada proofing box selama \pm 1 jam.

i. Pemanggangan pada suhu $180^{\circ} \mathrm{C}$ selama 25 menit.

\section{Analisis senyawa bioaktif pada DALMS dan FTT}

Analisis senyawa bioaktif pada DALMS dan FTT menggunakan HPLC meliputi: tokoferol dan tokotrienol (Mitei et al., 2009), fitosterol (Mitei et al., 2009), dan skualen (Lau et al., 2005). 
Analisis karakteristik DALMS dan FTT

a. Kadar asam lemak bebas (Mehlenbacher, 1960 dalam Sudarmadji et al., 2003).

b. Bilangan peroksida metode ferriklorida (Kim, 2005).

c. Bilangan p-anisidin (IUPAC, 1993).

\section{Analisis karakteristik roti}

a. Analisis daya kembang (Yuwono dan Susanto, 1998).

b. Analisis tekstur (Tensile Strenght) (Yuwono dan Susanto, 1998).

c. Analisis densitas kamba (Yuwono dan Susanto, 1998).

\section{Uji hedonik roti}

Uji hedonik roti meliputi warna, aroma, rasa, dan tekstur. Jumlah panelis yang digunakan sebanyak 30 panelis.

\section{HASIL DAN PEMBAHASAN}

\section{Karakteristik DALMS, FTT, dan roti tawar}

Distilat asam lemak minyak sawit merupakan hasil samping proses pemurnian CPO (Crude Palm Oil) yang mengandung asam lemak bebas, senyawa hasil oksidasi, dan senyawa bioaktif (vitamin E (tokoferol dan tokotrienol), firosterol, dan skualen) dalam jumlah minor. Karakteristik DALMS yang berkaitan dengan potensi oksidasi dapat dilihat dari jumlah asam lemak bebas (Tabel 1). Produk hasil oksidasi pada minyak dapat digambarkan dengan bilangan peroksida pada awal terjadinya oksidasi dan bilangan $p$-anisidin bila telah terjadi oksidasi lanjut. Kandungan asam lemak bebas, bilangan peroksida, dan bilangan $p$-anisidin dapat dilihat pada Tabel 1.

Tabel 1. Karakteristik DALMS, FTT DALMS, roti tawar

\begin{tabular}{clccc} 
No. & Komponen & ALB $(\%)$ & Bil. Peroksida $(\mathbf{m e q} / \mathbf{k g})$ & Bil. $\boldsymbol{P}$-anisidin \\
\hline 1. & DALMS & 92,49 & 3,06 & 3,31 \\
2. & FTT DALMS & 2,14 & 1,65 & 3,08 \\
3. & Roti Tawar & 0,78 & 0,82 & 2,28 \\
\hline
\end{tabular}

Jumlah asam lemak bebas pada DALMS sebesar 92,49\%, merupakan angka yang tinggi karena DALMS merupakan hasil samping pemurnian CPO pada tahapan deodorisasi yang bertujuan memisahkan asam lemak bebas dari CPO. Pada proses deodoorisasi bersama-sama asam lemak bebas terikut juga senyawa vitamin $\mathrm{E}$ (tokoferol dan tokotrienol), fitosterol, dan skualen. Hasil penelitian Chang et al. (2016) pada beberapa industri minyak sawit kandungan asam lemak bebas pada DALMS bervariasi antara $65,70-94,68 \%$ tergantung kualitas CPO, sementara Islam et al (2016) mendapatkan kandungan asam lemak bebas dalam DALMS sekitar 86,44\% Pada penelitian ini dilakukan proses penyabunan yang bertujuan untuk mendapatkan senyawa bioaktif dari DALMS. Asam lemak bebas bereaksi dengan $\mathrm{KOH}$ pada proses penyabunan membentuk sabun sementara fraksi tidak tersabunkan mengandung senyawa bioaktif. Fraksi Tidak Tersabunkan (FTT) mengandung asam lemak bebas dalam jumlah kecil $(2,14 \%)$ karena asam lemak telah membentuk sabun pada proses penyabunan. Sementara pada roti tawar terjadi sedikit peningkatan karena asam lemak bebas (2,78\%) kemungkinan disebabkan karena proses pemanasan (pemanggangan) menyebabkan terjadi hidrolisis dari minyak yang terkandung dalam roti tawar.

Bilangan peroksida dan bilangan $p$ anisidin berbeda di antara DALMS, FTT, dan pada roti. Bilangan peroksida dan bilangan $p$-anisidin DALMS, FTT, dan pada roti tawar dapat dilihat ada Tabel 1. Bilangan peroksida dan bilangan $p$-anisidin DALMS tertinggi yaitu sebesar 3,06 mek/kg dan 3,31. Tingginya bilangan peroksida dan p-anisidin disebabkan karena DALMS juga merupakan akumulasi produk hasil oksidasi. Hasil penelitian Chang et al. (2016) bilangan peroksida pada DALMS berkisar antara 1,02$15,89 \mathrm{mek} / \mathrm{kg}$. Penurunan bilangan peroksida $(1,68 \mathrm{mek} / \mathrm{kg})$ dan bilangan p-anisidin $(3,08)$ pada FTT terjadi karena produk hasil 
oksidasi yang di dalam DALMS mengalami penyabunan. Sementara pada roti tawar penurunan bilangan peroksida $(0,82 \mathrm{mek} / \mathrm{kg})$ dan bilangan $p$-anisidin telah tercamur di dalam bahan dan meleawti proses pengolahan menyebabkan konsentasi bilangan peroksida dan bilangan $p$-anisidin menurun.

\section{Senyawa bioaktif pada fraksi tidak tersabunkan (FTT)}

Fraksi tidak tersabunkan adalah fraksi yang telah dipisahkan dari proses penyabunan DALMS, dimana asam lemak bebas mengalami penyabunan sementara senyawa bioaktif terkandung di dalam fraksi tidak tersabunkan yang larut dalam heksan. Fraksi Tidak tersabunkan mengandung vitamin E 8.464,14 $\mathrm{mg} / 100 \mathrm{~g}$, fitosterol $36.134,79 \mathrm{mg} / 100 \mathrm{~g}$, dan skualen $3.183,39$ $\mathrm{mg} / 100 \mathrm{~g}$ (Tabel 2). Jumlah senyawa bioaktif yang terkandung pada FTT bervariasi bergantung pada kandungan DALMS dan efektivitas proses penyabunan. Di dalam FTT untuk vitamin E, $\alpha$-tokotrienol merupakan tertinggi sebesar $60,95 \%$, kelompok fitosterol $\beta$-sitosterol 75,99\%, dan skualen. Hasil penelitian Norhidayah et al. (2012) memperoleh kandungan skualen 418,13 ppm di dalam DALMS. Menurut Akinfalabi et al. (2017) DALMS mengandung asam lemak bebas $85 \%$, trigliserida $10 \%$, dan senyawa dalam jumlah kecil seperti vitamin E, sterol, dan skualen.

Tabel 2. Kandungan senyawa bioaktif dalam FTT DALMS

\begin{tabular}{lcc}
\hline \multicolumn{1}{c}{ Senyawa Bioaktif } & & \\
\cline { 2 - 3 } & $\mathbf{m g} / \mathbf{1 0 0} \mathbf{g}$ & \%relatif \\
\hline Kadar Vitamin E & $\mathbf{8 . 4 6 4 , 1 4}$ & \\
$\alpha$-tokoferol & 749,38 & 8,85 \\
$\alpha$-tokotrienol & $5.158,94$ & 60,95 \\
$\delta$-tokotrienol & 624,86 & 7,37 \\
$\gamma$-tokotrienol & 1931,96 & 22,83 \\
Total Tokotrienol & $\mathbf{7 . 7 1 4 , 7 9}$ & \\
Total Fitosterol & $\mathbf{3 6 . 1 3 4 , 7 8}$ & \\
$\beta$-sitosterol & $27.462,36$ & 75,99 \\
Stigmasterol & $2.166,79$ & 5,99 \\
Kampesterol & $6.505,63$ & 18 \\
Skualen & $\mathbf{3 . 1 8 3 , 3 9}$ & \\
\hline
\end{tabular}

Proses penyabunan memisahkan antara fraksi tersabunkan dan fraksi tidak tersabunkan sehingga akan meningkatkan konsentrasi senyawa yang pada fraksi tidak tersabunkan. Fraksi Tidak Tersabunkan DALMS komponen terbesarnya berupa fitosterol dan vitamin E. Hasil penelitian Mitei et al. (2009) FTT mengandung tokoferol sebesar $33,84 \%$ dan tokotrienol sebesar $66,16 \%$. Ahmadi et al (2012) juga menyatakan bahwa FTT DALMS mengandung $\alpha$-tokoferol sebesar 11.844 ppm, $\alpha$-tokotrienol sebesar $7.441 \mathrm{ppm}, \gamma$ tokotrienol sebesar $13.464,5 \mathrm{ppm}$ dan $\delta$ tokotrienol sebesar 2.250,5 ppm. Pada penelitian ini, FTT mengandung $\alpha \alpha$-tokoferol sebesar 7.493,84 ppm, $\delta$-tokotrienol sebesar
$6.238,85 \mathrm{ppm}$ dan $\gamma$-tokotrienol sebesar $19.319,61 \mathrm{ppm}$.

\section{Karakteristik fisik roti tawar mengandung FTT}

Karakteristik fisik roti yang difortifikasi FTT digambarkan dengan tiga parameter, yaitu volume pengembangan, tekstur, dan densitas kamba. Hasil penelitian menunjukkan tidak terdapat pengaruh nyata fortifikasi FTT pada pembuatan roti tawar untuk masing-masing taraf perlakuan $(0 ; 0,5$; $1,0 ; \quad 1,5 ; 2,0 ; 2,5 \%)$. Gambar 1a menunjukkan rata-rata volume pengembangan roti tawar berkisar antara 51,75 - 61,25 mm, Gambar 1b menunjukkan rata-rata tekstur roti tawar berkisar antara 6,13 - 8,60 N, dan Gambar 1 menunjukkan rata-rata densitas berkisar antara 0,40-0,51. 


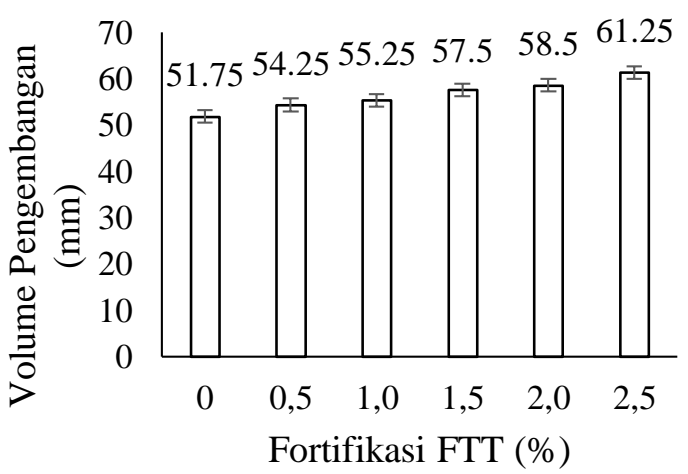

(a)

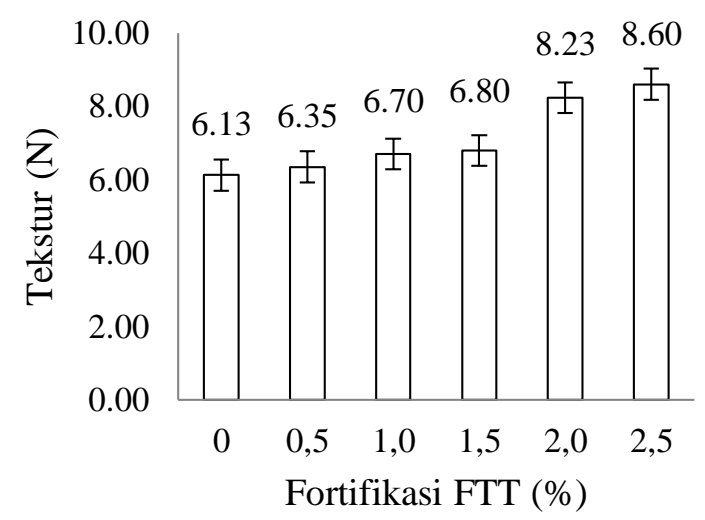

(b)

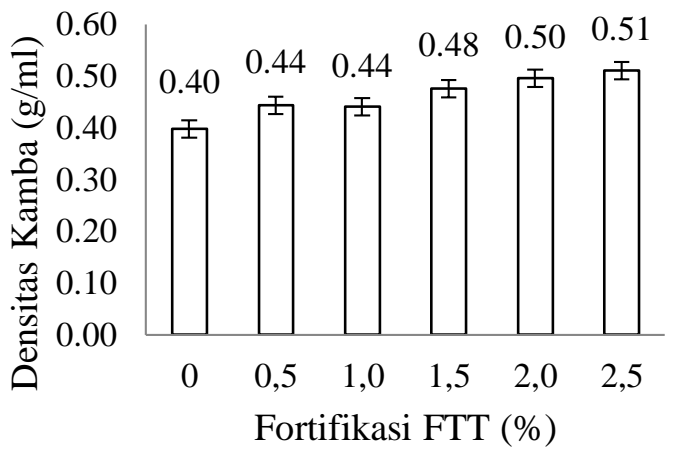

(c)

Gambar 1. Hubungan Fortifikasi FTT dengan Volume Pengembangan (a), Tekstur (b), dan densitas kamba (c)

Hasil ini menunjukkan hasil yang baik karena sampai dengan taraf fortifikasi tertinggi $(2,5 \%)$ FTT tidak mempengaruh sifat fisik roti tawar yang dihasilkan. Fortikasi FTT tidak mempengaruhi performa fisik roti tawar sehingga secara keragaan roti yang difortifikasi dan tanpa fortifikasi penampilannya sama.

Karakteristik fisik roti tawar (volume pengembangan, tekstur, dan densitas kamba) dipengaruhi oleh gluten yang terkandung di dalam terigu yang digunakan sebagai bahan pembuatan roti. Hasil penelitian Eduardo et al. (2015) gluten dalam terigu mempengaruhi gaya kohesif dan viscoelastis selama pengadonan dan mempertahankan gas yang dibentuk selama fermentasi. Selama fermentasi enzim amilase berperan membentuk $\mathrm{CO}_{2}$, meningkatkan kemampuan retensi gas selama pengadonan, dan meningkatkan volume pengembangan dan struktur pori (Ertugay, 2010). Menurut Zao et al. (2020) gluten menentukan tekstur roti tawar karena gluten mempengaruhi struktur roti yang dibentuk.

Volume pengembangan, tekstur, dan densitas kamba (bulk density) saling berkaitan volume pengembangan yang baik akan mempengaruhi tekstur dan densitas kamba. Pada penelitian ketiga parameter tersebut sama untuk semua taraf perlakuan yang diberikan. Peningkatan fortifikasi FTT pada adonan roti tidak mempengaruhi sifat fisik roti. Kualitas fisik roti banyak dipengaruhi oleh adanya gluten dalam terigu. Menurut Dhaka dan Khatkar (2015) gluten meningkatkan volume pengembangan adonan dan pemanggangan sehingga berpengaruh terhadap tekstur dan densitas kamba.

\section{Uji organoleptik roti tawar}

Uji organoleptik dilakukan terhadap warna, aroma, rasa, dan tekstur. Hasil ratarata uji organoleptik disajikan pada Gambar 2. Rata-rata responden memberikan penilaian yang suka (4) pada roti tawar tanpa difortifikasi FTT dibandingkan dengan taraf fortifikasi yang lain. Fortifikasi FTT pada roti tawar memberikan pengaruh yang baik dengan menurunkan kesukaan panelis. Jika dibandingkan di antara perlakuan fortifikasi maka fortifikasi $0,5 \%$ memberikan penilaian agak suka. Hal ini menunjukkan semakin tinggi taraf fortifikasi FTT panelis makin tidak suka. 
Warna roti tawar yang difortifikasi FTT mengalami perubahan warna yang tidak disukai panelis. Warna yang timbul cenderung lebih gelap dibandingkan dengan roti tawar tanpa fortifikasi FTT, dan perubahan warna semakin meningkat dengan meningkatnya fortifikasi FTT. Warna FTT sedikit kekuningan hal ini yang menyebabkan adanya perubahan warna tersebut, semakin meningkat fortifikasi FTT perubahan semakin meningkat.

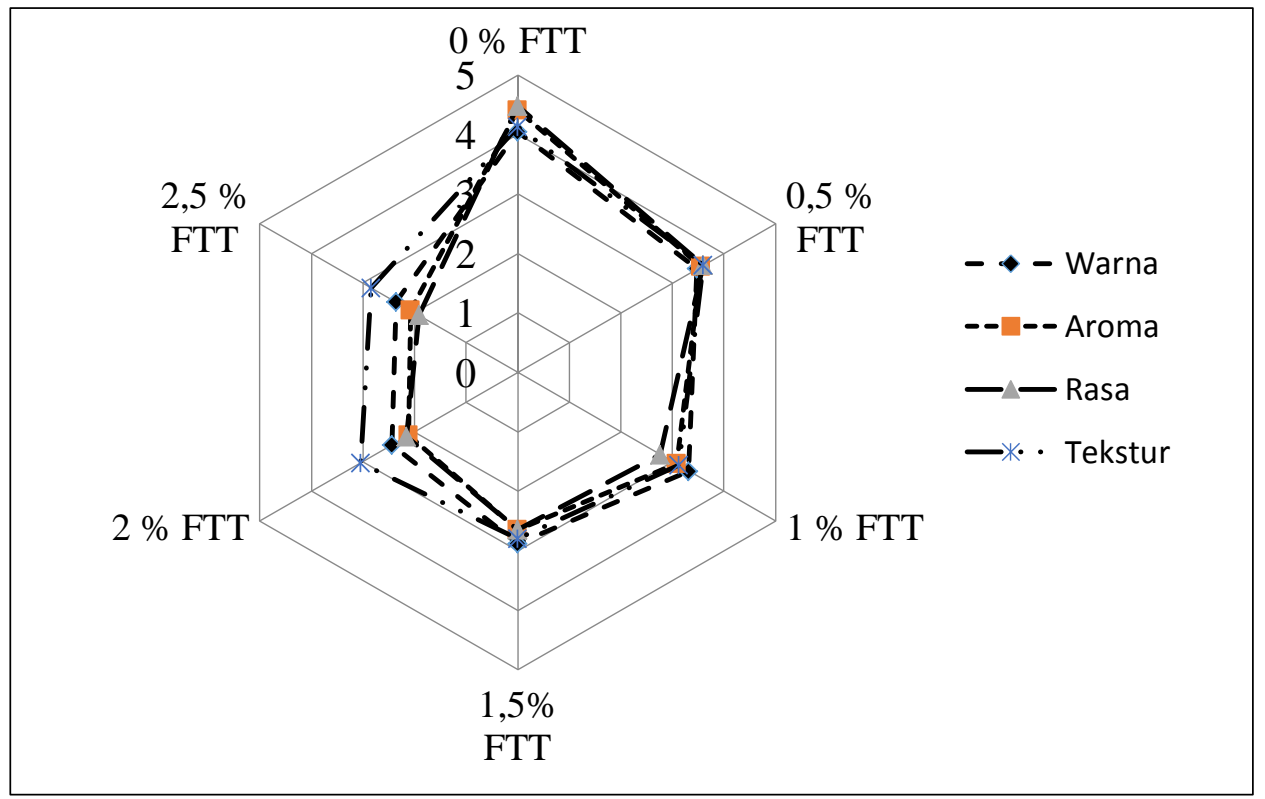

Gambar 2. Hasil uji organoleptik roti tawar

Aroma roti tawar yang difortifikasi dengan FTT menghasilkan aroma yang kurang disukai panelis dibandingkan dengan roti tawar yang tanpa fortifikasi FTT. Akibat fortifikasi FTT aroma yang dihasilkan menutupi aroma khas roti tawar, ini menyebabkan roti yang diforifikasi kurang disukai. Perubahan aroma ini semakin meningkat dengan meningkatnya tingkat fortifikasi FTT. Batas toleransi yang masih dapat diterima panelis adalah pada fortifikasi $0,5 \%$, fortifikasi $1-2,5 \%$ menurunkan tingkat kesukaan. Aroma yang timbul ini disebabkan karena roti tawar yang difortifikasi FTT mengandung asam lemak bebas $0,78 \%$. Asam lemak bebas merupakan senyawa yang bersifat mudah teroksidasi dan mudah menguap. Hasil oksidasi asam lemak bebas menyebabkan aroma yang tidak disukai. Menurut Min dan Boff (2002) asam lemak bebas akan terdekomposisi membentuk senyawa yang lebih sederhana volatil yang menghasilkan aroma yang tidak enak dari oxidative rancidity.

Rasa roti tawar mengalami perubahan akibat fortifikasi FTT dibandingkan dengan tanpa fortifikasi FTT. Di antara perlakuan fortifikasi FTT, fortifikasi FTT 0,5\% masih lebih disukai dibandingkan dengan fortifikasi lainnya $(1,0-2,5 \%$ FTT $)$. Hasil analisis pada roti yang diforfikasi FTT $0,5 \%$ menunjukkan mengandung asam lemak bebas sebesar 0,78\% yang berasal dari FTT dimana asam lemak bebas pada FTT 2,14. Asam lemak bebas adalah senyawa yang juga mempengaruhi rasa dari produk.

Tekstur roti tawar dengan fortifikasi FTT mengalami perubahan dibandingkan dengan tanpa fortifikasi FTT. Penilaian panelis menunjukkan terjadi penurunan kesukaan terhadap roti yang difortifikasi FTT. Hasil penilaian ini berbeda dengan hasil analisis sifat fisik roti tawar. Pada hasil analisis fisik tidak terjadi perbedaan antara roti tawar tanpa fortifikasi FTT dengan roti tawar yang difortifikasi FTT.

Kandungan asam lemak bebas pada roti yang difortifikasi FTT berpotensi untuk mengalami oksidasi dan akan mempengaruhi sifat sensoris roti tawar. Menurut Chaiyasit et al. (2007) oksidasi lemak merupakan salah satu penyebab kerusakan alami dan makanan 
yang diproses. Kerusakan oksidatif mendapatkan perhatian besar dalam industri makanan karena mempengaruhi kualitas terutama menyebabkan ketengikan, perubahan warna, tekstur, dan nilai nutrisi makanan.

\section{KESIMPULAN}

Dari penelitian ini dapat disimpulkan bahwa fortifikasi FTT DALMS sampai 2,5\% tidak mempengaruhi karakteristik fisik (volume pengambangan, tekstur, dan densitas kamba) roti tawar. Kemudian roti tawar tanpa fortifikasi FTT DALMS paling disukai untuk warna, aroma, rasa, dan tekstur, sedangkan untuk roti tawar yang difortifikasi FTT DALMS $0,5 \%$ lebih disukai untuk warna, aroma, rasa, dan tekstur.

\section{UCAPAN TERIMA KASIH}

Ucapan terima kasih disampaikan kepada DRPM Dikti, Kemristekdikti yang telah membiayai penelitian ini melalui Skim Penelitian Strategis Nasional dengan Kontrak Perjanjian Pelaksanaan Penugasan Penelitian Nomor: 039/SP2H/P/K7/KM/2015, tanggal 2 April 2015 melalui DIPA Kopertis Wilayah 7

\section{DAFTAR PUSTAKA}

Ahmadi, K., \& Estiasih, T. (2011). Kristalisasi pelarut suhu rendah pada pembuatan fraksi kaya vitamin e mengandung tokotrienol dari distilat asam lemak minyak sawit. Jurnal Teknologi dan Industri Pangan, 22(2), 142-142.

Ahmadi, K., Kumalaningsih, S., Wijana, S., \& Santoso, I. (2012). Optimizing vitamin $\mathrm{E}$ purification from unsaponifiable matter of palm fatty acids distillate by low temperature solvent crystallization. Journal of Food Science and Engineering, 2(10), 557563.

Akinfalabi, S. I., Rashid, U., Yunus, R., \& Taufiq-Yap, Y. H. (2017). Synthesis of biodiesel from palm fatty acid distillate using sulfonated palm seed cake catalyst. Renewable Energy, 111, 611619.

https://doi.org/10.1016/j.renene.2017.0 4.056

Arifianti, A., Anandito, R. B. K., Affandi, D. R., \& Parnanto, N. H. R. (2012). Karakterisasi bubur bayi instan berbahan dasar tepung millet (Panicum sp) dan tepung beras hitam (Oryza sativa L. Japonica) dengan flavor alami pisang ambon (Musa paradisiaca var. sapientum). Jurnal Teknosains Pangan, 1(1), 96-104.

Chaiyasit, W., Elias, R. J., McClements, D. J., \& Decker, E. A. (2007). Role of physical structures in bulk oils on lipid oxidation. Critical reviews in food science and nutrition, 47(3), 299-317. https://doi.org/10.1080/1040839060075 4248

Chang, A. S., Sherazi, S. T. H., Kandhro, A. A., Mahesar, S. A., Chang, F., Shah, S. N.,... \& Panhwar, T. (2016). Characterization of palm fatty acid distillate of different oil processing industries of Pakistan. Journal of oleo science, 65(11), 897-901. https://doi.org/10.5650/jos.ess16073

Dhaka, V., \& Khatkar, B. S. (2015). Influence of gluten addition on rheological, pasting, thermal, textural properties and bread making quality of wheat varieties. Quality Assurance and Safety of Crops \& Foods, 7(3), 239249.

Eduardo, M., Svanberg, U., \& Ahrné, L. (2016). Effect of hydrocolloids and emulsifiers on the shelf-life of composite cassava-maize-wheat bread after storage. Food Science \& Nutrition, 4(4), 636-644. https://doi.org/10.1002/fsn3.326

Ertugay, Z., (2010). The quality relationship between wheat, flour and bread. Atatürk University, Journal of Agricultural Faculty, 13, 165-176.

Estiasih, T., Ahmadi, K., Widyaningsih, T. D., Maligan, J. M., Mubarok, A. Z., Zubaidah, Mukhlisiyyah, J., \& 
Puspitasari, R. (2013). Bioactive compounds of palm fatty acid distillate (PFAD) from several palm oil refineries. Advance Journal of Food Science and Technology, 5(9), 11531159.

Gapki. (2020). Kinerja industri sawit Indonesia 2019. Jakarta: Gabungan Pengusaha Sawit.

Islam, A., Masoumi, H. R. F., Teo, S. H., Abdollahi, Y., Janaun, J., \& TaufiqYap, Y. H. (2016). Glycerolysis of palm fatty acid distillate for biodiesel feedstock under different reactor conditions. Fuel, 174, 133-139. https://doi.org/10.1016/j.fuel.2016.01.0 88

Kapor, N. Z. A., Maniam, G. P., Rahim, M. H. A., \& Yusoff, M. M. (2017). Palm fatty acid distillate as a potential source for biodiesel production-a review. Journal of cleaner production, 143, 19.

https://doi.org/10.1016/j.jclepro.2016.1 2.163

Kim, J. S. (2005). Radical scavenging capacity and antioxidant activity of the $\mathrm{E}$ vitamer fraction in rice bran. Journal of food science, 70(3), C208-C213. https://doi.org/10.1111/j.13652621.2005.tb07127.x

Min, D. B., \& Boff, J. M. (2002). Lipid oxidation of edible oil. Food Science and Technology-New York-Marcel Dekker-, 335-364.

Mitei, Y. C., Ngila, J. C., Yeboah, S. O., Wessjohann, L., \& Schmidt, J. (2009). Profiling of phytosterols, tocopherols and tocotrienols in selected seed oils from Botswana by GC-MS and HPLC. Journal of the American Oil Chemists' Society, 86(7), 617-625. https://doi.org/10.1007/s11746-0091384-5

Nang Lau, H. L., Puah, C. W., Choo, Y. M., Ma, A. N., \& Chuah, C. H. (2005). Simultaneous quantification of free fatty acids, free sterols, squalene, and acylglycerol molecular species in palm oil by high-temperature gas chromatography-flame ionization detection. Lipids, 40(5), 523-528. https://doi.org/10.1007/s11745-0051413-1

Norhidayah, S., Baharin, B. S., Hamed, M. A., \& Zaidul, I. S. M. (2012). Squalene recovery from palm fatty acid distillate using supercritical fluid extraction. International food research journal, 19(4), 1661.

Posada, L. R., Shi, J., Kakuda, Y., \& Xue, S. J. (2007). Extraction of tocotrienols from palm fatty acid distillates using molecular distillation. Separation and Purification Technology, 57(2), 220229.

https://doi.org/10.1016/j.seppur.2007.0 4.016

Sudarmadji, S., Bambang H., \& Suhardi. (2003). Prosedur analisis untuk bahan makanan dan pertanian. Yogyakarta: Liberty.

Veršilovskis, A., \& Bartkevičs, V. (2012). Stability of sterigmatocystin during the bread making process and its occurrence in bread from the Latvian market. Mycotoxin research, 28(2), 123-129.

https://doi.org/10.1007/s12550-0120124-0

Yuwono, S. S., \& Susanto, T. (1998). Pengujian Fisik Pangan. Malang: Universitas Brawijaya. 